IZA DP No. 4609

Financial Dependence, Formal Credit, and Informal Jobs: New Evidence from Brazilian Household Data

Luis A. V. Catão

Carmen Pagés

Maria Fernanda Rosales

December 2009 


\title{
Financial Dependence, Formal Credit, and Informal Jobs: New Evidence from Brazilian Household Data
}

\author{
Luis A. V. Catão \\ Inter-American Development Bank \\ and IMF \\ Carmen Pagés \\ Inter-American Development Bank \\ and IZA
}
Maria Fernanda Rosales
University of Chicago
Discussion Paper No. 4609
December 2009

\author{
IZA \\ P.O. Box 7240 \\ 53072 Bonn \\ Germany \\ Phone: +49-228-3894-0 \\ Fax: +49-228-3894-180 \\ E-mail: iza@iza.org
}

\begin{abstract}
Any opinions expressed here are those of the author(s) and not those of IZA. Research published in this series may include views on policy, but the institute itself takes no institutional policy positions.

The Institute for the Study of Labor (IZA) in Bonn is a local and virtual international research center and a place of communication between science, politics and business. IZA is an independent nonprofit organization supported by Deutsche Post Foundation. The center is associated with the University of Bonn and offers a stimulating research environment through its international network, workshops and conferences, data service, project support, research visits and doctoral program. IZA engages in (i) original and internationally competitive research in all fields of labor economics, (ii) development of policy concepts, and (iii) dissemination of research results and concepts to the interested public.
\end{abstract}

IZA Discussion Papers often represent preliminary work and are circulated to encourage discussion. Citation of such a paper should account for its provisional character. A revised version may be available directly from the author. 


\section{ABSTRACT \\ Financial Dependence, Formal Credit, and Informal Jobs: New Evidence from Brazilian Household Data}

This paper examines a much overlooked link between credit markets and formalization: since access to bank credit typically requires compliance with tax and employment legislation, firms are more likely to incur such formalization costs once bank credit is more widely available at lower cost; if so, well-functioning credit markets help foster formal employment at the expense of informal jobs. We gauge the relevance of this credit channel using the RajanZingales measure of financial dependence and a difference-in-differences approach applied to household survey data from Brazil - a large emerging market where substantial changes in banking system depth and formalization ratios have taken place and for which consistent data exists. Our results show that formalization rates increase with financial deepening and the more so in sectors where firms are typically more dependent on external finance. We also decompose shifts in aggregate formalization into those within each firm size category and those associated with changes in firm size, and find that financial deepening significantly explains the former but not so much the latter.

JEL Classification: E26, G21, O4, O16

Keywords: credit markets, financial dependence, informality, Brazil

Corresponding author:

Luis A. V. Catão

Research Department

Inter-American Development Bank

1300 New York Ave.

Washington DC 20577

USA

E-mail: Icatao@iadb.org

\footnotetext{
* The authors are grateful to Eduardo Fernández-Árias as well as seminar participants at the IADB, LACEA, the World Bank, and IZA Institute for Labor for comments on an earlier draft. Lucia Madrigal provided able research assistance. The opinions presented in this paper are the authors' alone and do not necessarily represent those of the Inter-American Development Bank, the International Monetary Fund, or their respective Boards of Directors.
} 


\section{Introduction}

Two basic tenets command considerable consensus in the financial and economic development literatures. One is that financial development is good for economic growth (Levine, 1997; Beck, Levine, and Loyaza, 2000). This because well-functioning financial markets make it easier for firms to attract financing for investment needs, and this is particularly crucial in sectors where productivity gains are potentially high but high dependence on external finance is a potential constraint (Rajan and Zingales, 1998). To the extent that the development of formal credit markets is hindered in countries with unsound economic policies, deficient property rights and law enforcement (La Porta et al., 1997; Johnson et al., 2002; Claessens and Laeven, 2003), the expansion of such high productivity sectors and of higher productivity but financially dependent firms therein will then be curbed; hence economic growth will suffer, all else constant.

The other basic tenet is that informality of firms and of employment arrangements broadly understood as the lack of compliance with taxes and regulatory provisions — is bad for growth. As shown in a host of recent studies, informality tends to undermine allocative efficiency as well as firm-level productivity, leading to under-investment and lower total factor productivity (Farrell 2006; Perry et al 2007; Levy, 2008; La Porta and Shleifer, 2008; Hsieh and Klenow, 2009). Further, to the extent that informality shrinks national tax bases and induces higher compensatory taxes to be levied on formal business, there is a perverse feedback from the prevalence of informality to higher 
taxation which reinforces the incentives to go informal. ${ }^{2}$ Thus, the adverse effects of informality on economy-wide productivity and growth can easily snowball, making it a pressing policy issue in many countries. This can be particularly so in times of financial distress, when formal employment falters, tax collection efforts step up, and incentives to evade and go informal thus thrive.

Notwithstanding this substantial body of literature on the links between financial development and economic growth on the one hand, and on informality and productivity growth on the other, there has been - to the best of our knowledge - a striking dearth of studies on the links between the functioning of formal credit markets and labor formalization. ${ }^{3}$ One might conjecture that such links can be quite important once informality is viewed as resulting from decisions by optimizing agents on the costs and benefits of going informal as in standard models (see Straub, 2007 and various references therein). This is because the cost of remaining either an unregistered firm or a registered firm in breach of tax obligations is that of having either limited or no access whatsoever to formal credit markets (cf. Fanjzylber et al., 2006; Gatti and Honorati, 2008; IDB, 2009). After all, to be able to borrow from banks or from other regulated financial intermediaries a firm typically needs not only to be formally registered (or in some cases

\footnotetext{
${ }^{2}$ See e.g. Djankov et al. (2002) for cross-country evidence linking high taxes, informality, and productivity growth. It highlights the positive relationship between high taxes on formal business and the size of the informal sector on the one hand, and the negative relationship between the size of the informal sector and per capita income gap relative to the US on the other. One form of compensatory tax which Djankov et al. (2002) do not consider, however, and which was widely practiced in the past is the inflation tax. Insofar as the inflation tax affects both formal and informal business, it does not per se foster tax evasion by formal business. Yet, to the extent that high and chronic inflation curbs financial development, it tends to foster informality via the very credit channel mechanism that we examine in this paper.

${ }^{3}$ For instance, in a widely cited Journal of Economic Literature survey on informality by Schneider and Enste (2000), no attention is paid to the financial development and the credit channel mechanism that we discuss in this paper. Instead, as in much of literature on informality, emphasis on is placed on the roles of taxation, employment regulations and a variety of other institutional factors.
} 
legally incorporated as a limited liability company), but also comply with considerable information requirements about its balance sheet and income flows so as to allow some of the usual information intensive monitoring of its activities by banks (cf. Fama, 1985). If anything, such requirements for tapping formal credit markets are likely to have become more stringent in recent years, as developments in communications and data gathering technology allow governments to pool and cross information from different enforcement agencies and thus more effectively clamp down on illegal borrowing and lending practices and the attendant tax evasion associated with informality. ${ }^{4}$ Moreover, potential incentives for formalization via such a "credit channel" can also "bite" through the employee's own optimizing behavior. For the lower the cost of bank credit, the greater the incentives for workers to take on formal jobs or demand legalization of their current employment situation, since having legal proof of steady earnings should allow better terms of access to credit more generally. In short, from the viewpoint of both the demand and the supply of formal jobs, financial development would tend to shrink the relative size of the informal sector.

This paper examines whether such opportunity costs may be empirically relevant. Specifically, we test two main hypotheses. First, we examine whether and to which extent such a "credit channel" can explain aggregate variations in formal vs. informal employment over and above other driving forces of formality, such as overall economic growth and tighter regulatory enforcement. Second, we examine whether this credit

\footnotetext{
${ }^{4}$ In the particular case of developing countries where public banks play an extensive (and sometime almost exclusive) role in providing credit to smaller and medium sized firms, such enforcement is likely to be even stronger. This is because the government (as the majority or only equity owner of such financial intermediaries) has an obvious incentive to cross-check information with regard to tax evasion and arrears with social security and, based on those records, restrict or deny altogether access to formal credit.
} 
channel works mainly through its effect within specific size categories and/or by shifting the composition of employment between firm sizes. Scrutinizing these effects is important to understand the main mechanisms through which financial development drives formalization. For instance, better access to credit among smaller firms (which are usually more credit constrained than larger firms) may lead them to grow, shifting into larger size segments of the market and leaving their previous size segment more dominated by smaller informal firms. If so, access to credit may well increase informality in the lower segments of the firm size distribution. But, it may also be the case that greater access to cheaper credit disproportionally benefits smaller firms, giving them greater incentive to formalize. Looking at such size-related effects may allow us to discern these possibilities and relate our findings to a sizeable literature on credit constraints and firm size. This is a matter of great analytical as well as practical interest since the prevalence of small business policies in many countries is predicated on the very basis of such constraints.

Our empirical analysis rests on four pillars. One is the definition of informality. We focus on formal employment - defined as those jobs in compliance with registration regulations and social security contributions - as our key measure of informality. We do so because this is a readily available measure from household surveys, and one which has a fundamental advantage over others: workers do not have obvious incentives to report that they are formal when they are informal, as opposed to firms' incentives to answer similar questions (since hefty penalties for non-compliance can be imposed on firms). Moreover, it is also quite a general measure of informality since the share of formal employment in 
total employment is often highly (negatively) correlated with other economy-wide measures of informality (IDB, 2009).

The second pillar of our testing methodology is the use of the classic measure of financial dependence advanced by Rajan and Zingales (1998). The basic idea is the existence of sectors which are structurally more dependent on external finance than others (using the US as the benchmark for building such a cross-sectional ranking). If so, such sectors and firms therein are the ones standing to benefit the most from an expansion of credit supply or financial deepening broadly defined. Hence the incentives to formalize should be higher in those sectors relative. To the best of our knowledge, this is the first time the Rajan-Zingales measure of financial dependence is used in the context of an analysis on the determinants of informality.

Third, we focus on bank credit. We do so because banks are by far the most important class of regulated financial intermediaries in emerging markets and developing countries regarding the provision of external credit to firms, and they remain so in many developed countries as well. If the postulated links between the depth of the banking system (what we will broadly call "financial deepening") and informality are significant, one should thus expect that for countries and/or periods in which the supply of bank credit is lower or subject to more frictions - resulting in high intermediation spreads and lending costs that are highly dependent on the firm's collateral - the opportunity cost of informality would be lower, all else constant; hence the share of informal jobs in total employment should be higher. Conversely, as the banking system becomes more efficient and firms 
have better terms of access to formal credit (including not being rationed out of formal credit markets altogether due to adverse selection or collateral constraints), overall formality should be higher.

Finally, we focus on Brazil for three reasons. One is data availability. Among developing countries, Brazil has one of the most thorough household surveys (the Pesquisa Nacional por Amostra de Domicilios, PNAD) with a wealth of employment data which is nationally representative and allows meaningful comparisons over time. In Brazil, there is also evidence of a very high correlation between a firm's registration, its tax compliance status, and its compliance with social security contributions (Carpio and Pagés, 2009). This makes data on social security and labor registration compliance from the PNAD a reasonably accurate indicator of degree of firm-level formalization in the economy at large. Other Brazilian macroeconomic data that we employ as additional controls in our testing methodology are also deemed to be consistently measured vis- $a$ vis their respective counterparts in some other developing countries. All this contributes to the reliability of our results.

Another important reason to focus on Brazil is the combination of substantial shifts in the formal/informal composition of employment and in the expansion and cost of bank credit over the years, what facilitates the identification of the effects at work. Last but not least, Brazil is an interesting case study from a policy experiment viewpoint. This is because it has combined in recent years financial liberalization with conservative macroeconomic and financial policies which sought to keep inflation low and stable and banks solidly 
liquid (through high reserve requirements and stringent capital regulations). One of the main visible effects of this combination has been an expansion of credit supply well in excess of GDP growth and declining intermediation spreads - only temporarily interrupted by the global financial crisis in late 2008. ${ }^{5}$ If such rapid financial deepening did contribute to a significant increase in formalization rates, this would be suggestive of a potentially important dividend of policies that combine the efficiency gains of financial liberalization (in terms of the availability and cost of domestic credit) with prudential regulations and conservative macro policies.

To preview our results, the paper finds evidence of a credit-formalization channel at work: formalization has been more pronounced in economic activities that are more financially dependent. We also highlight that a main conduit is through shifts in the formality rate within each firm size category, particularly among firms who employ labor other than the owner's own. To a lesser extent, we also find some evidence that financial deepening shifts the composition away from self-employment and towards larger firms.

The remainder of the paper is divided into five sections as follows. Section 2 and 3 below describe the data and main stylized facts, including a decomposition of "between" and "within" effects behind changes in formalization rates. Section 4 lays out our

\footnotetext{
${ }^{5}$ The positive effect of financial liberalization on bank credit to GDP and financial deepening more broadly is clearly not a unique feature of the Brazilian experience but holds quite generally. See Bekaert, Harvey, and Lundblad (2005, table 2) for evidence spanning 95 countries. Bekaert et al. (2005) also find that while financial liberalization predicts additional financial development, the decision to liberalize does not seem to be influenced by the degree of financial development and can thus be taken as broadly exogenous to it. This lends further support to the exogeneity assumption underpinning our results as discussed below.
} 
identification approach and econometric results. Section 5 discusses robustness. Section 6 concludes.

\section{Data}

As discussed in the introduction, this paper adopts an employment-based measure of formality which has the advantage of being less prone to misrepresentation and reliably tracked from household data. In addition, this measure is useful because it is highly correlated with the formality status of a firm: unregistered firms cannot enroll their workers in social security, although there may be some registered firms that do not enroll their workers in social security because they are only in partial compliance with regulations. In this regard, it is possible that some firms take steps toward formalizing their activities but have not fully regularized their labor force. If anything, this implies that our measure may lead us to find lower effects of bank credit on formalization than if we were using firm registration as the measure of formality.

We work with two alternative definitions of formal employment. One is to define as formal those workers with a formal employment contract ("carteira assinada"). This arrangement denotes the fact that to register a worker, employers need to make an entry in a pocketsize booklet ("carteira") that all workers must have. The other defines formal workers as those who report contributing to social security. While there is typically a tight match between the two, this need not be one-to-one. This is because there are workers who are not formal employees of a private firm, government, or other institution and still contribute to social security either because they have their own business (self- 
employed) or form a cooperative with other workers. In the event, the correlation between these two alternative measures of formalization has been quite tight in Brazil. ${ }^{6}$

Data on formal employment is obtained from the Pesquisa Nacional por Amostra de Domicilios (PNAD), the main Brazilian household survey which employs a consistent measurement methodology for the years 2002-2007. This survey is nationally representative and contains information of an average of 394.000 individuals in 118.000 households each year, covering all sectors of economic activity. The sample used here corresponds to salaried and self employed individuals between 15-65 years old who work in non-agricultural activities. Employers, domestic workers, military personnel, and unpaid workers are excluded.

The PNAD contains information on whether workers are self-employed (firms of one person), work in firms of 2-10 employees, or in firms of more than 10 employees. Whether this size division may seem quite restrictive it should be noted that the large majority of establishments in Latin America are very small, with between 80-90 percent of manufacturing establishments below 10 employees (IDB, 2009) ${ }^{7}$.

Cross sectional information on employment is aggregated at the sector level, at a 2 digit of aggregation (ISIC rev3) to construct formalization ratios by sector and size category computed as total number of formal workers divided by total number of workers in a given sector and size category. In addition, we also compute the share of employment in

\footnotetext{
${ }^{6}$ Data reported in Table 1 on the growth of formalization rates across sectors for the period 2002-2007 yield a correlation coefficient between these two alternative formalization measures of 0.82 .

${ }^{7}$ Comparable figures for the United States are 55.4 percent according to the latest US Census.
} 
self-employment, in firms with 2-10 employees, and in larger firms in each sector. While in principle, we have information for 40 sectors, we drop information for sectors with less than 80 observations per year in the data. Also, as customary in the literature of financial constraints and firm growth (see, e.g. Fazzari, Hubbard, and Petersen, 1988), financial industries (financial intermediation, activities auxiliary, insurance and pension fund) are excluded from the sample. After this filtering, we have data for 25 sectors for the selfemployment group, 26 sectors for the 2-10 employees size category, and 40 sectors for the larger firm group.

The second foundation of our data work consisted of building sector-specific measures of external financing dependence following the classic methodology of Rajan and Zingales (1998). In their work, the authors compute indices only for manufacturing. In order to obtain similar economy-wide measures that can be mapped into the PNAD's double-digit aggregation level (as per the ISIC rev3 classification), we use information obtained from the sample of firms in the S\&P 1500 index (available at Bloomberg) for the years between 2002 and 2006. Financial dependency indices are computed as the ratio between capital expenditures minus cash from operations (use of external finance) and capital expenditures. As in Rajan and Zingales (2008), for each firm the index is calculated first as the sum of external finance over 2002-2006 divided by the sum of capital expenditures in the same period. Then, the industry sector median is calculated again aggregating at a 2 digit classification (ISIC rev 3). As discussed in Section 5, we also compute a coarser discrete measure of financial dependency by assigning a value of 1 if the sector index lies 
above the mean, and 0 otherwise, to capture sectors with a financial dependency above and below the mean, respectively.

Finally, we use a classic measure of financial deepening at the country-year level which is total domestic bank credit to GDP. For the reasons discussed later, we break this aggregate credit variable into credit to the private sector as a whole (i.e., including firms and households but excluding the government) and credit to private firms only (i.e. excluding households and government). To gauge financial deepening more broadly, we also consider measures of the cost of credit such as interest rates and banking spreads, as well as real GDP growth, real exchange rate changes and inflation as additional controls. All financial sector and macro data were obtained from the Brazilian Planning Ministry Research Institute (http://ipeadata.gov.br), with the exception of the real effective exchange rate index which is a series internally produced at the IMF.

\section{Stylized Facts}

Figure 1 shows that formalization - as measured by the share of workers with carteira assinada - has risen significantly since 2003 , from $38 \%$ to nearly $45 \%$ of the urban labor force by early 2008. One observes a similar upward trend using the alternative definition of formality based on the share of workers who contribute to social security (Figure 2). Using either definition, the rate of formality has displayed a clear upward trend since 2004. 
As mentioned above, this upward trend in formality takes place pari pasu with an upward trend in credit growth. The more widespread use of banking financing by the private sector since 2004 is clearly depicted in Figure 3, which shows that the ratio of overall credit to the private sector (i.e. including both credit to firms and households) rose relative GDP over the past five year, reaching an all time high by early 2008 of nearly 38\%. No less importantly, credit to firms has also risen sharply over the same period. Starting from a much lower base, it reached 22\% of GDP by early 2008 from a trough of 15\% around mid-2003. Since real GDP growth accelerated during this period, this implies that credit growth has been especially strong, expanding at double-digit annual rates.

This credit expansion has taken place at declining interest rates. Not only did the policycontrolled money market rate declined, but so did lending rates charged by banks to the average borrower. No less importantly, the banking intermediation spread (lendingdeposit rate) has declined almost monotonically during the period, suggesting improvements in credit risk and/or intermediation efficiency - factors that have typically accounted for high banking spreads in Brazil as well as much of Latin America (Gelos, 2008). This juxtaposition of declining rates and lending growth suggests that rightward shifts in the supply of loans are driving these trends. The result has been better terms of access by firms to formal banking credit.

Thus, a first inspection in trends in credit conditions and formal employment provides prima-facie evidence for a positive relationship between the two. Further, given that the 
credit boom is seemingly associated with expansionary shifts in credit supply due to mostly (if not entirely) exogenous factors - such as declining policy-controlled interest rates, favourable international liquidity, and improvements in intermediation efficiency (all facilitated by liberalization policies), this suggests that the causality runs from better terms of access to credit markets to employment formalization.

In practice, growing formalization of firms and labor arrangements may take place through a complex mix of channels operating "within" and "between" sectors as well as across firm sizes. First, informal firms may decide to become legal, and being legal implies complying with firm and workers registration as well as profit and labor tax obligations. Second, formal firms may expand faster and hence displace informal firms. Third, formal firms (in the sense that they are registered or pay some taxes) engaged in informal practices (in the sense that do not comply with all their obligations) may regularize these practices so as to avoid the risk of "being caught", which can potentially undermine their terms of access to formal credit. Fourth, even if firms could obtain credit when informal, increased access to credit allows them to grow; this size effect of abundant credit in turn provides incentives to become formal to the extent that enforcement increases with firm size (i.e. smaller firms are less likely to be “caught”). Available data for Brazil (as well for most other countries) do not allow us to directly measure the relative importance of these different channels. This is because one can only derive from the PNAD net flows by sector, rather than individual firms' entry and exit (i.e. gross flows). Nor does the survey provide information on the age of the firm or on whether it began its life as an informal or formal establishment. Despite these limitations, 
we do glean useful information on the relative importance of some of these "within" and "between" effects from these data.

Consider first the variations in formality rates across industries shown in Table 1 . The expansion of formalization has been reasonably widespread across sectors, suggesting that much of the increase in aggregate formalization appears to have taken place via "within sector" effects. Yet, there are also important differences across sectors. For example, taking the formalization of the contract ("carteira assinada”) definition, the results suggest that formality rates ranged from a low of $30 \%$ or so in some service activities to a high of $97 \%$ in the manufacture of coke, refined petroleum products and nuclear fuel. The data also indicates that this broad picture is robust to the measure of informality adopted.

Further insights into the channels driving formalization during the period can be gleaned from a more disaggregated look at the composition of employment. We start with a simple decomposition exercise by firm size. This is important in light of a distinguished literature on financial constraints and economic growth that argues that smaller firms are typically the more constrained ones and hence typically have more to gain from the expansion of credit supply (e.g. Gertler and Gilchrist, 1994; Carpenter and Petersen, 2002). The extent to which the growth in aggregate formality is associated with shifts in employment shares across distinct firm size categories ("between” effect) vs. shifts in formalization inside the various firm size segments (“within” effect) can be derived as 
follows. Let $F$ be aggregate formal employment while $E$ is total employment (including both formal and informal workers), so that we can write:

$$
\frac{F}{E}=\frac{F^{L}}{E}+\frac{F^{S}}{E}
$$

where superscripts L and S stand for total formal employment in large and small firms respectively. Dividing and multiplying the first term of the right hand side by $E^{L}$ and the second term by $E^{S}$ and differentiating through yields:

$$
\begin{aligned}
\Delta\left(\frac{F}{E}\right) & =\Delta\left(\frac{F^{L}}{E^{L}}\right) \frac{E^{L}}{E}+\Delta\left(\frac{E^{L}}{E}\right) \frac{F^{L}}{E^{L}}+\Delta\left(\frac{F^{S}}{E^{S}}\right) \frac{E^{S}}{E}+\Delta\left(\frac{E^{S}}{E}\right) \frac{F^{S}}{E^{S}} \\
& \overbrace{\text { within L }} \overbrace{\text { between L \& S }} \overbrace{\text { within S }}^{\text {between S \& L }}
\end{aligned}
$$

The first and the third terms on the right of (2) account for the growth formalization within each of the two size categories, whereas the second and fourth terms account for changes in the shares of employment between large and small firms. It is easy to see that further size breakdowns add extra pairs of terms to the left of (2).

Table 2 presents the results using both definitions of formality ("carteira” and social security contributions). Because the self-employed do not have a labor contract (i.e. they are not employees), this category is excluded from the breakdown by the "carteira" definition. Since the PNAD does not allow further size breakdowns for firms with more 
than 11 employees, then our working definition of small firms comprises those which employ between 2 and 10 employees, while the definition of larger firm comprises those that employ 11 or more employees.

Starting with the "carteira" definition, it is clear that much of the increase in formalization is due to a positive "within effect" among smaller and larger firms. This within effect is of similar magnitude across the two size categories (41.6 percent and 40.1 percent) over the entire 2002-2007 period. It became stronger during the 2004-2007 credit boom, rising to 44.7 and 43.8 percent, respectively. This is broadly corroborated by the decomposition based on the "social security" definition, with the intermediate and larger firm sizes posting the highest gains in 2004-2007 (35.1 percent and 33.1 percent, respectively). This contrasts with the weaker formalization effect of 6.7 percent within the self-employed category.

But an important contribution to formalization also comes from shifts in relative firm size - the "between" effect. In the first part of the period, this effect was in fact predominant and stemming from the growing share of larger firms, i.e., the size segment where formalization is higher to start with. Interestingly, this "between" stemming from the relative expansion of larger firms becomes weaker in the latter part of the period (particularly in 2006-2007 when credit expansion sharply accelerates). The flip side of these developments is that the smaller firm size segment diminishes its share in total employment. In particular, the reduction of informality has been associated with the 
relative decline of the self-employment category throughout 2002-2007. ${ }^{8}$ Similarly the share of employment in the middle-size segment has also contracted during 2002-2007 but less so in 2004-2007 and particularly in 2007. This suggests that as the credit boom matures, there appears to be some trickle-down effect, reducing the speed of the loss of participation of smaller firms in total formal employment.

While the overall negative (albeit decelerating) between effect for smaller firms would seemingly go against the evidence that smaller firms tend to be the ones which are more credit constrained, care needs to be taken about interpreting this. First because the larger firm segment as defined as those encompassing firms with 11 or more employees still comprises a sufficiently large number of small and medium firms which are typically credit constrained. Second, because, even though larger firms are typically less credit constrained, larger firms in emerging economies in Latin America are still small in worldwide terms (Herrera and Lora, 2006). So, these larger firms still stand to benefit greatly from easier credit access enabling them to expand market shares. Third, because we need controls for other effects that affect size. We will consider them in Section 5.

One should also bear in mind that the computed percentage shares in Table 2 refer to a net effect. In other words, to the extent that easier credit access allows a growing number of firms to move from the smaller to the larger size segment, this may well account for such a skewness effect in the size distribution. Since the available PNAD data does not allow us to pin down gross flows, it remains a matter of conjecture as to which effect predominates - i.e., whether smaller firms are disappearing and having their market

\footnotetext{
${ }^{8}$ In fact, this relative reduction is observed every single year between 2002 and 2007.
} 
shares taken over by previously existing larger firms or simply that many smaller firms are rapidly growing in size and joining the rank of larger firms.

In sum, evidence from these simple descriptive exercises with the raw data indicates that better terms of access to formal credit are helping foster aggregate formalization of the labor force. This favorable credit effect appears to be taking place on two fronts. One is by motivating formerly informal firms to go formal, particularly for firms with more than one employee. The other front is by increasing the weight of larger firms -traditionally with a higher propensity of being formal. In turn, the latter effect may be driven either by credit allowing small firms to grow or by credit boosting growth among already formal and larger firms.

\section{Econometric Evidence}

We now formally test whether economic sectors that are typically more dependent on external financing (which, as discussed above, means domestic bank credit) are the ones where formal employment expands faster as the terms of access to bank credit improve. To gauge the extent to which different sectors have different degrees of financial dependence, we follow the classic methodology of Rajan and Zingales (1998), where the degree of financial dependence (hereafter FD) of each sector is measured based on US data. The underlying assumption is that because the United States has the world's most developed financial system, the observed degrees of financial dependence of different sectors in the United States reflect their "true" financial dependence as determined by technological factors. While the Rajan-Zingales methodology has been used to pin down 
the determinants of per capita income growth across countries, the novelty in our empirical testing strategy is to apply their identification approach to examine determinants of labor formalization rates, in this case across a host of sectors in one country.

As in Rajan and Zingales (1998), the sector-level measure of financial dependence is then interacted with the economy-wide measures of financial deepening discussed in Section 2, i.e., bank credit to the private sector over GDP or credit to private firms to GDP. The reason we also take into account the first measure is because it is possible that firms use other categories of credit not formally defined as "business credit" for their financing; in this case, the broader category of bank credit would be the more appropriate measure.

As discussed above, firm size dimension appears to be crucial to the dynamics of the relationship between access to formal credit and formalization of the labor force. So, in addition to results for the overall rate of formalization, and as in the simple decomposition exercise of Section 2, the econometric estimates presented below will also distinguish formalization by size categories. Among other things, such a size breakdown also helps ensure that our financial dependency variable is not (or at least not entirely) capturing size effects. As above, results are presented for categories within salaried employment (firms 2-10 employees and firms of 11 or more workers) as well as separately for the self-employed. 
To test whether such changes in formal employment within each firm size category have been stronger in sectors which are more financially dependent of external resources, we estimate the following model:

$$
f_{j t}^{C}=\beta_{0}^{C}+\delta_{t}^{C}+\delta_{j}^{C}+\gamma^{C}(\text { Credit/GDP })_{t} * F D_{j}+\varepsilon_{j t}^{C},
$$

where $j, t, C$ represent sector, year and firm size category respectively. The dependent variable corresponds to the formalization share in size category $c$. FD stands for the Rajan-Zingales index explained above, whereas $\delta_{t}$ and $\delta_{j}$ are year and sector dummies.

In addition, to gauge the extent to which employment shifts across firm size categories (between effects) are stronger in more financially dependent sectors, we also estimate the following model where the dependent variable is defined as the share of employment of firm size category $\mathrm{C}$, in sector $\mathrm{j}$, year $\mathrm{t}$, over total employment in sector $\mathrm{j}$, year $\mathrm{t}$.

$$
\left(\frac{E^{c}}{E}\right)_{j t}=\lambda_{0}{ }^{C}+\delta_{t}^{C}+\delta_{j}^{C}+\rho^{C}(\text { Credit/GDP })_{t} * F D_{j}+\varepsilon_{j t}^{C}
$$

Before moving onto the results, two points should be born in mind. One is that the FD*credit variable is strongly exogenous to the individual sector, since the FD variable is constructed on the basis of US (rather than Brazilian) data and aggregate credit is mostly exogenous to each sector, especially at the finer (2-digit) level of disaggregation we work with. Second, it is worth noting that since we construct our dependent variables as 
averages within each size-sector cell, and because we drop cells based on less than 80 (unweighted) observations, the number of observations in our formalization regressions of equation (3) varies by firm size. Instead, for the set of regressions corresponding to equation (4) we only include sectors for which the number of unweighted observations is more than 80 across all firm sizes. This is because otherwise the sum of the shares of employment by sector across regressions would not add up to one.

The regressions were estimated by Generalized Least Square (GLS) allowing the standard error to follow a first-order autocorrelation specific to each sector. It should also be noted that the use of time effects is particularly important in this context since among other common aggregate influences (like real GDP growth), they are also capturing common improvements in regulatory enforcement which may have been important in Brazil during this period.

We start by testing the overall relationship between financial deepening and formalization without breaking down by size, i.e., pooling all firm sizes together. Table 3 presents the results. They clearly indicate that formalization generally increases with financial deepening, and with coefficients that are very similar across the two definitions of formalization (“carteira” and "social security”). An increase in aggregate credit to firms/GDP by 10 percentage points relative to average would increase formalization in the most financially dependent sector (air transport - see Table 1) relative to the least financially dependent sector (manufacture of paper and paper products - see Table 1) by some 6.5 percentage points [ $=(1.27-(-1.67)) * 0.1 * 0.22]$. 
The results also indicate that the effect is about twice as strong for the credit to firms variable than for the variable credit to the overall private sector (i.e. firms+households).. This is consistent with the hypothesis that firms' dependence on external financing is the key engine of formalization, rather than household dependence on credit in general. In other words, an increased supply of firm credit creates better incentives for formalization than consumption credit. Thus, the difference between the two types of credit often lies in the fact that, while firm owners may obtain consumption credit quite easily without presenting any financial statement or information on the legal status of the firm, obtaining firm credit - which is generally offered at much better terms as Brazilian data clearly indicates - requires presenting detailed information on firms' activities and legal status. Thus, the strength of the credit-formalization channel under consideration clearly depends on the formalization status of the firm being a pre-condition for credit. We return to the implications of this key result in Section 6.

Tables 4 and 5 provide evidence on the extent to which formalization responds to aggregate credit availability across distinct size segments. Table 4 starts with the "carteira" definition of formality for which only two size categories are available (since, as noted above, self-employed workers are not in salaried employment and therefore do not have "carteira assinada"). The results indicate that greater access to formal credit increases the probability of formalization both for smaller and larger firms. All effects are statistically significant at 1 percent. These results are consistent with the existence of a strong positive "within" effect of an expansion of credit supply or financial deepening as 
usually measured on formal employment on all firm size categories. As before, effects are twice as large for firm credit as for overall credit, and tend to be larger for smaller firms, lending support to the notion that smaller firms benefit more from increased access to credit.

Table 5 replicates the exercise for the social security definition of formality, which allows us to gauge what happens to the self-employed category. As in the "carteira" definition, the results point to a reasonably strong and statistically significant effect of credit availability on labor formalization for firms of 2-10 and larger firms. In contrast, the effects for the self-employed are statistically insignificant, albeit positive throughout.

As stated in the introduction, increased formalization due to increased credit may be outweighed by firms shifting into larger size segments of the market and leaving their previous size segment more dominated by informal firm. This may be particularly the case for self-employed workers. Yet, it may well be that this group is notoriously difficult to formalize. Given a strong relationship between size and productivity (see, e.g., IDB, 2009 for recent evidence and further references), the cost-benefit calculation for the smallest firms may be strongly tilted against formalization. This is the conclusion reached by Bruhn (2008) after evaluating the formalization outcomes of a business registration simplification program in Mexico. While she found that the program contributed to increased formalization, only very small effects were found among informal own-account firms. Nonetheless, since the contribution to overall formalization of within effects for the self-employed category is small, as seen in Table 2, this means 
that we are not leaving unexplained a large share of shifts in aggregate labor formalization.

Table 6 reports the estimation results for the "between" effect regressions highlighted in the decomposition scheme of equation (1). The dependent variable in the regression is now the ratio of employment in a certain firm size category to total employment. As such, the respective regressions capture the effect of credit availability on the distribution of employment across the three firm size categories. Notice that, as mentioned above, regressions only include sectors for which enough observations are encountered to compute reliable employment ratios in each size category. The results suggest that credit availability has an ambiguous between effect: none of the coefficients is statistically significant at conventional levels with the exception of one case, that referring to self employment and using as the measure of financial deepening credit to GDP. The results suggest that, if anything, increased access to credit reduces the share of the self-employed and increases the share of workers in firms of two or more employees. This inference is somewhat reinforced once further controls are introduced in the regressions as shown in Section 5.

This weaker effect of credit on the size distribution of employment is consistent with the presence of offsetting effects on the entry to and exit from each size group: on the one hand, increased access to credit may have motivated some formerly salaried workers to step into self-employment. On the other hand, some self-employed workers may have benefit from increased access to credit, hiring some employees and turning into 
intermediate size formal firms, thus contributing to reducing the share of employment in self-employment activities. The estimates suggest that on average the net effect of these two forces is negative, with a net exit of workers from self-employment to salaried jobs. Similar effects may be occurring for intermediate size firms, while some self-employed workers may have hired additional workers and turned into small firms, this effect may be offset by the move of some firms initially in the intermediate size category to the larger size category. The data suggest that these countervailing effects may be canceling each other out to a large extent. Since our data only captures the net effects, credit is thus bound to appear as explaining relatively little of the changes in formality associated with shifts in the size distribution of firms.

Once again, while this latter result may be read as inconsistent with the literature on credit constraints and the size distribution of firms (smaller firms are the ones typically to expand more rapidly with releasing of such constraints), care must be taken in doing so. As noted in Section 3, this is because our larger firm segment also comprises a number of firms which are still small by standard metrics. In addition, even the largest firms in emerging markets are typically far more credit constrained than those in the US market the focus of that literature - simply because emerging market countries themselves face much more stringent credit constraints overall. Be that as it may, the finding that the bulk of the financial deepening effect on formalization is working within the various firm size segments is striking, and has not been documented elsewhere to the best of our knowledge. 


\section{Robustness}

The results so far indicate that our findings are robust to the use of different formality measures (formality of the contract versus social security contributions) and different measures of credit (credit to the private sector versus credit to firm). We have also shown, however, that the effect of credit on formalization is stronger in the case of firm credit and that this is important supportive evidence for our hypothesis.

In this section we report results when we: (i) use a coarse index of financial dependence based on a dummy variable; (ii) try alternative measures of financial development and cost of credit; (iii) weight sectors by the number of observations and eliminate outlier sectors; and (iv) consider further controls.

Starting with (i), one might conjecture that the Rajan-Zingales FD ranking is highly demanding in terms of sectoral disaggregation and that the specifics of such ranking of financial dependence may not be entirely appropriate an economy such as Brazil, which is structurally quite distinct economy from the United States. With this potential criticism in mind, we re-run the regressions of Tables 3 to 5 replacing the FD index by a dummy variable, defined as 1 if the sector has an above-average FD index and zero otherwise. The results are reported in Table 7. The broad thrust of the results is that the financial dependence-financial deepening interaction is a positive determinant of formalization, although the coefficients are less precisely estimated, particularly for the 2-10 workers size group. Yet, as will be seen below, the significance of the coefficients on mid- 
segment of the size group using the FD dummy is re-instated once other alternative measures of financial deepening are considered.

Second, we assess whether our results hold when alternative measures of financial deepening are considered. We start with the money market interest rate as a measure of financial development instead of the ratio of aggregate bank credit to GDP. Since the money market interest rate in an emerging economy responds to a host of domestic policy as well as international developments such as global liquidity conditions, it is arguably a more exogenous determinant of credit availability and hence of financial deepening; it is also a more direct measure of the cost of credit. The results, presented in columns 1 and 2 of Table 8A, indicate findings which are very similar to those found with the other measures of credit in the baseline regressions of Tables 3 to 5: that is, a decline in interest rates is associated with increased formalization of workers employed in firms of two or more employees, with stronger results in the intermediate size. As before, the estimated coefficients also take on the expected sign among the self-employed, though they are not statistically significant at conventional levels. Coefficients are also very similar in size and significance regardless of the measure of external dependency used.

Regarding the allocation of employment across firm size, results are again suggestive that a reduction in interest rates promotes a shift of employment from self to salaried employment (Table 8B), but the results are only statistically significant when the FD dummy for high/low external dependency (instead of the finer R-Z ranking) is used. Table 9 shows that similar inferences emerge once we consider the intermediation spread 
(the difference between the average bank lending rate to firms and the money market interest rate) as a measure of financial deepening. To the extent that intermediation spreads reflect a combination of factors related to the level of money market rate, perceived lending risk, taxes, and the efficiency in the intermediation technology - all of which are arguably weakly exogenous to loan demand at the very least - they provide further indication that our baseline results on significance in Tables 3-5 are not undermined by endogeneity biases.

Turning to the treatment of sectors, rather than eliminating sectors with less than 80 observations, we investigate whether results change if in the formalization rate specifications we weigh each observation by the share of total observations in that sector. i.e. we assign higher weight to sectors with more observations and where the rates of formalization are more precisely estimated. The results are practically identical to those presented in tables 3-6 and so are not reported to conserve on space, but are available from the authors upon request.

Finally, we control for a common set of macroeconomic variables to which all sectors are exposed, instead of introducing time effects as in previous regressions. This has the advantage of allowing us to recover the full effects of an increase in overall credit on formality which in our baseline specification was absorbed by the time dummies. It also allows gauging how formalization and changes in relative market shares by firm size groups are affected by key macro variables such as real GDP growth and real exchange 
rate variation. The results are reported in Table $10 .{ }^{9}$ Clearly, the positive effects of financial dependence and availability of formal credit on formalization continue to hold in the presence of such controls. In fact, the respective coefficients are of a similar magnitude to those in the baseline specification of tables 5 to 6 . Regarding the significance of these controls, an interesting effect is that a rise of real GDP growth or a depreciation of the real exchange rate (measured so that an increase of RER corresponds to an appreciation) is associated with a increase in the formalization of the selfemployed. In contrast, a real appreciation allows large firms to grow relative to smaller firms. Thus, the introduction of such controls help explain some of the between effects highlighted in Table 2.

\section{Conclusion}

This paper assesses the potential of an empirically unexplored channel to explain changes in labor formalization and in informality more generally. The key hypothesis it tests is whether the combination of financial dependence and greater availability of cheaper credit (financial deepening) increases firms' incentives to become formal. This is so because formalization buys access to such an expanded supply of formal credit and thus saves on the higher costs and legal insecurity of informal credit markets. Given the wellknown literature that relates credit constraints and firm size, we also explore how access to credit changes formalization rates within firm size categories, as well as shifts in the composition of employment across size categories.

\footnotetext{
${ }^{9}$ We have also included inflation as a co-variate but the results on the relevant credit variables remain unchanged. A downside of including inflation is its colinearity with the real exchange rate. The coefficients on both variables are statistically significant in the overwhelming majority of the specifications.
} 
Our results indicate that the main effect of credit on formalization takes place via an incentive to formalize labor arrangements within each sector. Generally, we find that, as the aggregate supply of formal bank credit increases leading to financial deepening, there is a significantly faster increase in the formalization rate in those sectors which are more dependent on external funds. At the same time, the effect of financial deepening on formalization via changes in the distribution size of firms is less clear-cut: there is evidence that the self-employment segment shrinks and that the middle-sized segment expands but the latter effect is not statistically significant. This is consistent with the predictions of a model where net employment effects depend on the effect of credit on entry and exit: it is possible that greater credit availability drives the self-employed to grow into the middle-sized category, whereas many firms in the middle-sized segment grow into the larger size segment. Whether this has been the case cannot be tested on the basis of our data, since it does not have information on gross employment flows. In addition, as mentioned above, the coarse disaggregation of firm sizes in the survey cautions against making stronger statements about size effects. In short, whether the expansion of the share of employment in larger firms is given by the growth of initially small firms or by the growth of initially larger firms is a matter left for future research. Likewise, the extent to which the increase in formalization within the various sectors stems from unregistered informal firms that go formal, as opposed to already registered firms that from a point in time onward regularize their tax and regulatory obligations, or from new firms that enter the market as formal from inception, is also a question that available data does not allow us to discern. As such, gauging the various micro mechanisms through which financial development helps foster formalization via the 
potentially complex dynamics of firm entry and exit and size effects is an important topic left for future research once data are available.

Nonetheless, some key practical implications can be derived from this paper's results. One is that the gains of an increased supply of credit are likely to go beyond the nontrivial benefits of having a higher share of the labor force in regular jobs and thus able to afford better health and pension benefits and thus reduce potentially large social liabilities to the government. In addition to these very tangible and immediate social benefits, there is also considerable evidence that formalization also leads to better resource allocation and hence to higher productivity and long-term income growth which adds to welfare (Djankov et al., 2002; La Porta and Shleifer, 2008; IDB, 2009). In the particular case of Brazil, such links between informality and economic growth have been forcefully argued elsewhere, and in recent years the relative size of informal economy has been deemed to explain up to 30 percent of the productivity gap between the United States and Brazil (e.g. Farell, 2001; Capp et al., 2005). Therefore, understanding what drives informality is a critical issue in financial and economic development.

Another implication of our results pertains to the design of public programs of credit subsidies to small enterprises, such as the much touted micro-credit programs in developing countries. If such programs are designed without the requirement that such firms comply with a host of regulations and financial obligations associated with formal employment, then the disciplinary role of access to formal credit in curbing informality is short-circuited. To the extent that non-market based restraints to informality do not 
appear to be extremely effective practice, short-circuiting such a market-based disciplinary device may be sub-optimal. So, the design of such highly popular programs needs careful consideration in this light.

Last but not least, our findings have implications for macroeconomic and financial sector policy management. Brazil has been one of a handful of emerging markets that combined financial liberalization with tighter liquidity regulations and conservative monetary and fiscal policies. Such policies - to the extent that they are conducive to great credit market efficiency and less volatile financial market conditions - appeared to have contributed to reducing informality by lowering the cost of credit to formal firms. Since lower informality has substantial micro and macro economic benefits, this adds to the desirability of such policies beyond the more standard macro arguments in their defense. This seems to encapsulate a valuable lesson not only for Brazil - looking back at its own pre-1990s record of unsound macro and regulatory policies - but also for other developing countries.

In summary, the lack of attention by the literatures on financial development and financial dependence to what drives the formalization of firms and employment relations has left a wide gap on our understanding of the links of financial development and economic growth. This is an important gap which we believe future research should seek to fill. Further work looking at the experiences of other countries with distinct financial and productive structures, as well as distinct legal frameworks, should yield further insights on this issue and perhaps generalize some of our findings. 


\section{References}

Beck, Thorsten, Ross Levine, and Norman Loyaza, 2000, "Finance and the Sources of Growth”, Journal of Financial Economics 58, pp.261-300.

Bekaert, Geert, Campbell R. Harvey, and Christian Lundblad, 2005, "Does Financial Liberalizaton Spur Growth”, Journal of Financial Economics 77, pp.3-55.

Bruhn, Miriam, 2008, "License to Sell: the Effects of Business Registration Reform on Enterepeneurial Activity in Mexico”, World Bank Policy Research Working Paper 4538.

Capp, Joe, Bill Jones, Heinz-Peter Elstrodt, Wiliam Bebb Jones “Reigning in Brazil's Informal Economy”, McKinsey Quarterly, 2005, Issue 1. p18-21.

Carpenter, Robert and Bruce Petersen, 2002, "Is the Growth of Small Firms Constrained by Internal Finance”? Review of Economics and Statistics 84, pp. 298-309.

Carpio, Susana and C. Pagés, 2009. ”Informality, Misallocation and Productivity in Brazil” IDB Mimeo.

Claessens, Stijn and Luc Laeven, 2003, "Financial Development, Property Rights, and Growth”, Journal of Finance 58, pp. 2401-2436.

Djankov, Simon, Rafael La Porta, Florencio Lopez-de-Silanes, and Andrei Shleifer, 2002, “The Regulation of Entry,” Quarterly Journal of Economics 117, pp. 1-37.

Fama, Eugene, 1985, “What's Different About Banks?”, Journal of Monetary Economics 15, pp. 29-39.

Fanzylber, Pablo, William Marloney, and Gabriel Montes Rojas, 2006, Releasing Constraints to Growth or Pushing on a String? The Impact of Credit, Training, Business Associations and Taxes on the Performance of Mexican Micro-Firms, World Bank Policy Research Working Paper 3807.

Farrell, Diana, 2001, "The hidden dangers of the informal economy" McKinsey Quarterly; 2001:3. 27-37.

Farrel, Diana, 2006, The Productivity Imperative: Wealth and Poverty in the Global Economy. McKinsey Global Institute. Harvard Business School Press.

Fazzari, Steven, Glenn Hubbard, and Bruce Petersen, 1988, "Financing Constraints and Corporate Investment,” Brooking Papers on Economic Activity 19, pp.141-206.

Gatti, Roberta and Maddalena Honorati, 2008, "Informality Among Formal Firms: Firmlevel, Cross-Country Evidence on Tax Compliance and Access to Credit,” World Bank Policy Research Working Paper 4476. 
Gelos, Gaston, 2009, “Bank Spreads in Latin America,” Economic Inquiry, forthcoming.

Gertler, Mark and Simon Gilchrist, 1994, "Monetary Policy, Business Cycles, and the Behavior of Small Manufacturing Firms," Quarterly Journal of Economics, CIX.

Herrera, Ana Maria and Eduardo Lora, "Why so Small? Explaining the Size of Firms in Latin America”, World Economy 28, pp. 1005-1028.

Hsieh, Chang-Tai and Peter Klenow, 2009, "Misallocation and Manufacturing TFP in China and India”, Quarterly Journal of Economics, forthcoming.

Inter-American Development Bank (IDB), 2009 The Age of Productivity: Transforming Economies from the Bottom Up. Washington DC._Forthcoming.

Johnson, Simon, John McMillan, and Christopher Woodruff, 2002, "Property Rights and Finance", American Economic Review 92, pp. 1335-56.

La Porta, Rafael, Florencio Lopez-de-Silanes, Andrei Shleifer, and Robert Vishny, 1997, Legal Determinants of External Finance, Journal of Finance 52, pp.1131-1150.

La Porta, Rafael and Andrei Shleifer, 2008, "The Unofficial Economy and Economic Development,” NBER working paper 14520.

Levine, Ross, 1997, "Financial Development and Economic Growth: Views and Agenda”, Journal of Economic Literature 35, pp. 688-726.

Levy, Santiago. 2008 "Good Intentions, Bad Outcomes: Social Policy, Informality and Economic Growth in Mexico" Brookings Institution Press, Washington DC.

Perry, Guillermo, William Maloney, Omar Arias, Pablo Fajnzylber, Andrew Mason and Jaime Saavedra-Chanduvi, 2008, "Informality: Exit and Exclusion". The World Bank, Washington DC.

Rajan, Raghuram, and Luigi Zingales. 1998. "Financial Dependence and Growth,” American Economic Review 88 (3): 559-86.

Straub, Stephane, "Informal Sector: The Credit Market Channel", Journal of Development Economics 78, pp. 299-321.

Schneider, F. and Enste, D., 2000, "Shadow Economies: Size, Causes, and Consequences,” Journal of Economic Literature 35, pp. 33-47. 
Figure 1. Brazil: Share of Urban Workers with Formal Employment Contrato ("carteira") in Economically Active Urban Population

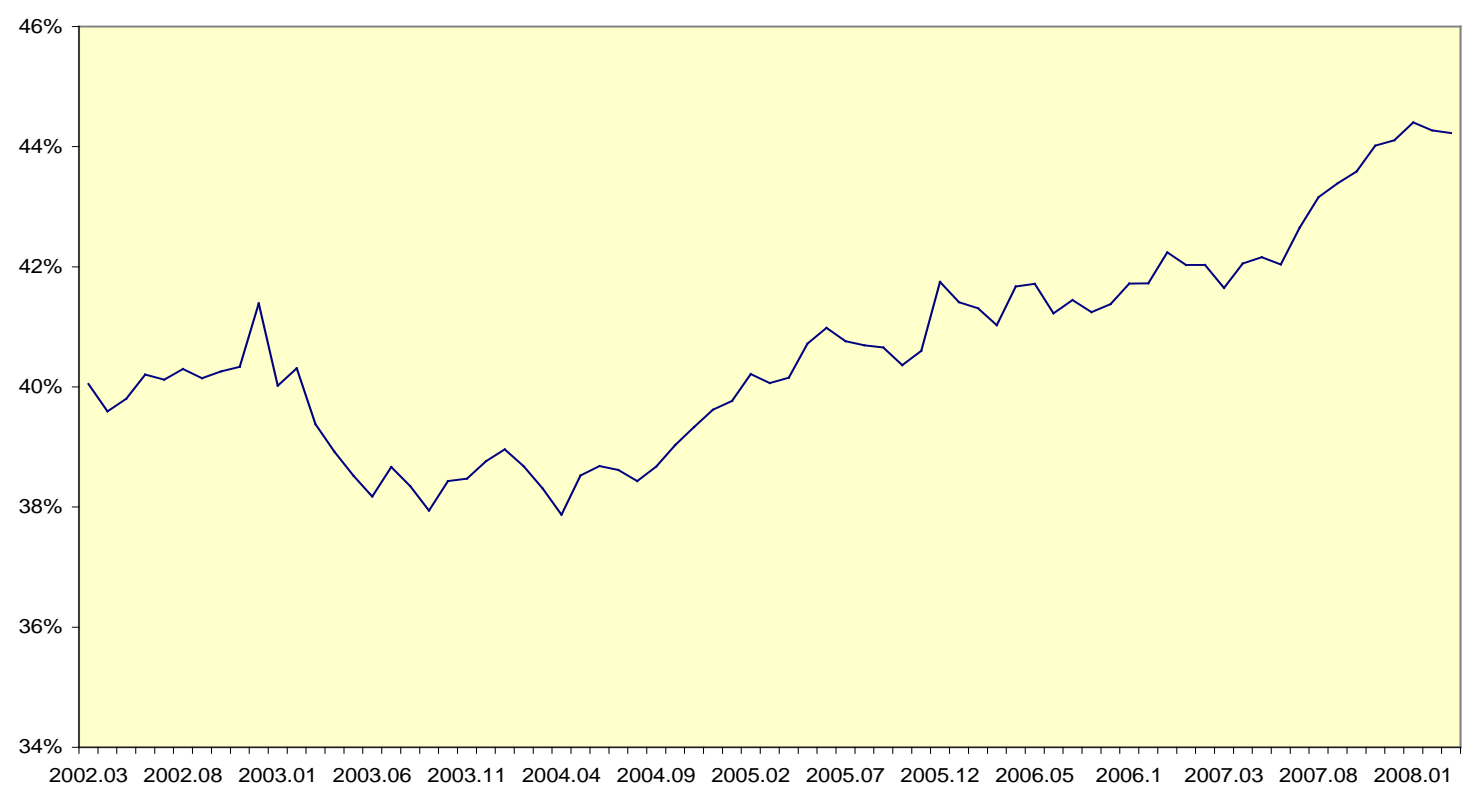

Source: Brazilian National Institute of Geography and Statistics (IBGE)

Figure 2. Share of Workers that Contribute to Social Security in Total Active Labor Force

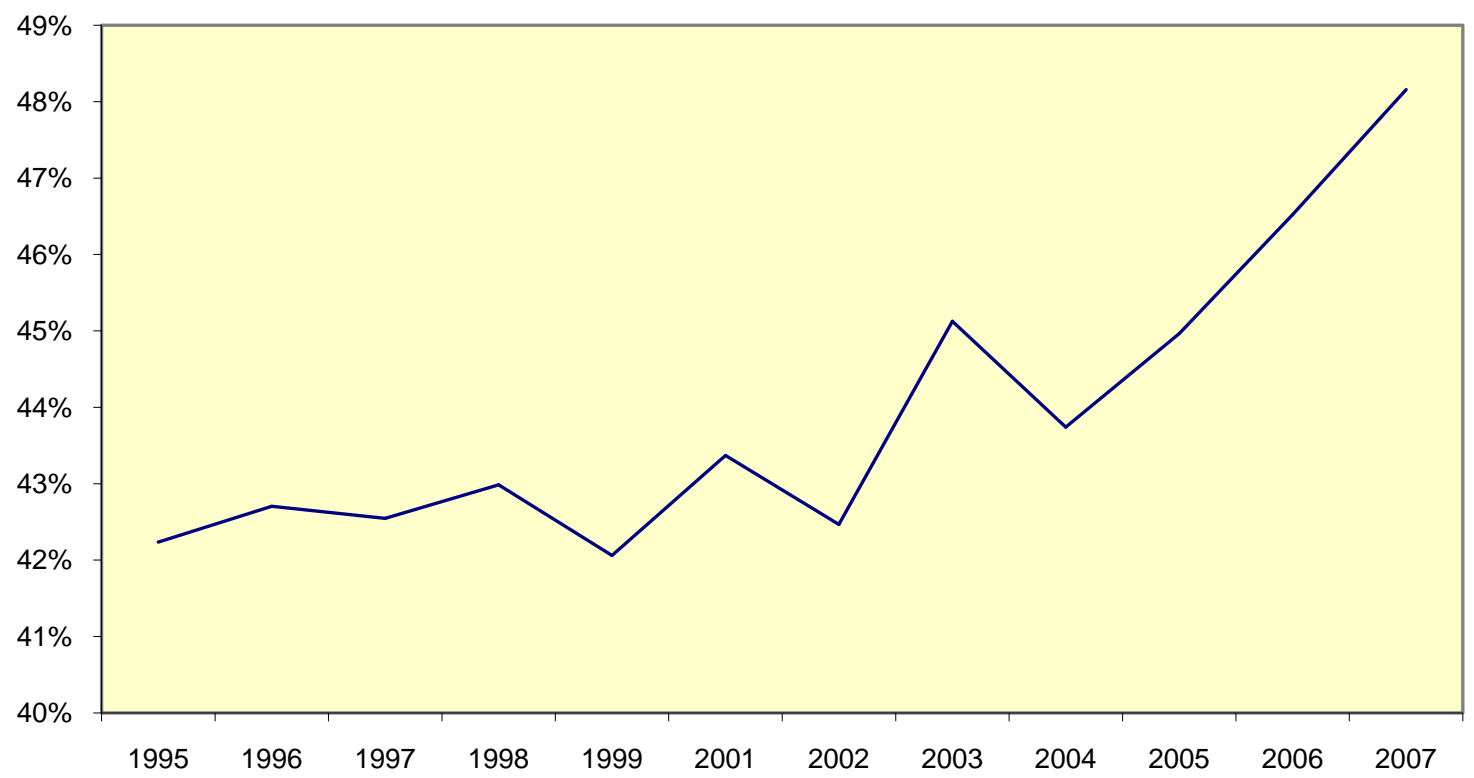

Source: Brazilian National Institute of Geography and Statistics (IBGE) 
Figure 3. Brazil: Bank Credit

(as share of GDP)

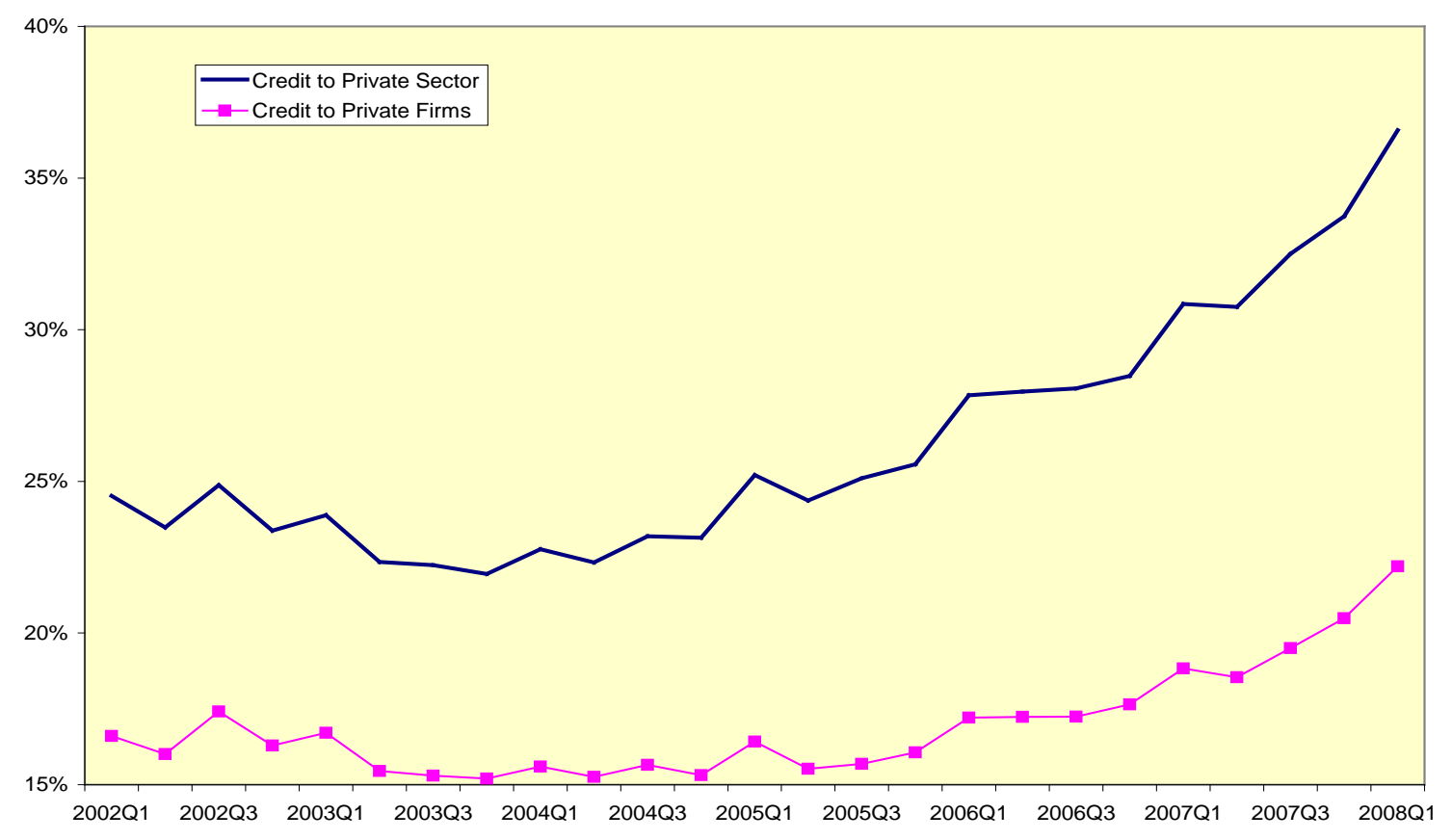

Source: Central Bank of Brazil and IPEA.

Figure 4. Brazil: Interest Rate Indicators

(\% a year)

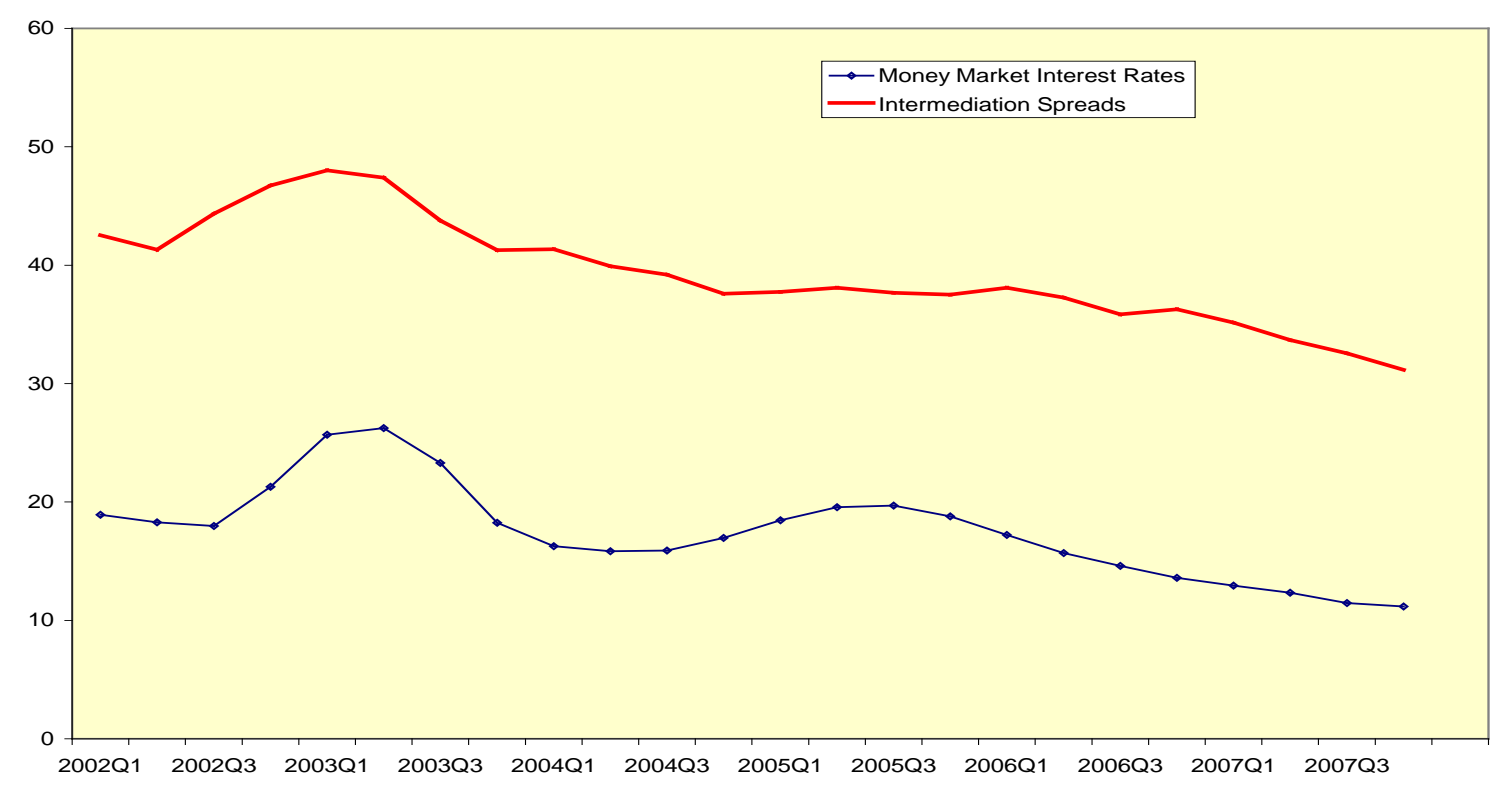

Source: Central Bank of Brazil and IPEA.. 
Table 1: Level and Change in the Share of Formal to Total Employment in Brazil and the Rajan-Zingales Financial Dependence (FD) Index

at a Two-digit Sectoral Disagregation

Formalization share - carteira definition

\section{isic_2dig Sector}

13 Mining of metal ores

14 Other mining and quarrying

15 Manufacture of food products and beverages

17 Manufacture of textiles

18 Manufacture of wearing apparel; dressing and dyeing of fur

19 Tanning and dressing of leather; manufacture of luggage, handbags, saddlery, harness and footwear

20 Manufacture of wood and of products of wood and cork, except furniture;

21 Manufacture of paper and paper products

22 Publishing, printing and reproduction of recorded media

23 Manufacture of coke, refined petroleum products and nuclear fuel

24 Manufacture of chemicals and chemical products

25 Manufacture of rubber and plastics products

26 Manufacture of other non-metallic mineral products

27 Manufacture of basic metals

28 Manufacture of fabricated metal products, except machinery and equipment

29 Manufacture of machinery and equipment n.e.c.

31 Manufacture of electrical machinery and apparatus n.e.c.

32 Manufacture of radio, television and communication equipment and apparatus

33 Manufacture of medical, precision and optical instruments, watches and clocks

34 Manufacture of motor vehicles, trailers and semi-trailers

35 Manufacture of other transport equipment

36 Manufacture of furniture; manufacturing n.e.c.

40 Electricity, gas, steam and hot water supply

45 Construction

50 Sale, maintenance and repair of motor vehicles and motorcycles; retail sale of automotive fuel

53 Wholesale trade, retail and commission trade, except of motor vehicles and motorcycles

55 Hotels and restaurants

60 Land transport; transport via pipelines

62 Air transport

63 Supporting and auxiliary transport activities; activities of travel agencies

64 Post and telecommunications

70 Real estate activities

72 Computer and related activities

74 Other business activities

75 Public administration and defence; compulsory social security

80 Education

85 Health and social work

90 Sewage and refuse disposal, sanitation and similar activities

92 Recreational, cultural and sporting activities

$79.1 \% \quad 80.8 \% \quad 1.7 \%$

Formalization share - social security definition

$81.1 \%-3.7 \%$

$54.5 \% \quad 75.8 \% \quad 21.3 \%$

$77.9 \% \quad 80.3 \% \quad 2.5 \%$

$77.0 \% \quad 78.8 \% \quad 1.8 \%$

$62.5 \% \quad 65.7 \% \quad 3.1 \%$

$69.0 \% \quad 67.8 \% \quad-1.2 \%$

$83.6 \%$

$74.5 \%$

$97.0 \%$

$81.3 \%$

$87.4 \%$

$68.9 \%$

$87.5 \%$

$75.2 \%$

$86.4 \%$

$85.8 \%$

$83.2 \%$

$82.9 \%$

$93.2 \%$

$83.9 \%$

$63.7 \%$

$90.6 \%$

$44.3 \%$

$57.8 \%$

$66.9 \%$

$59.9 \%$

$70.6 \%$

$96.0 \%$

$70.4 \%$

$80.9 \%$

$78.6 \%$

$73.8 \%$

$73.7 \%$

$63.3 \%$

$71.4 \%$

$80.3 \%$

$87.2 \%$

$49.6 \%$

$31.8 \%$
$88.7 \%$

$76.4 \%$

$96.8 \%$

$87.2 \%$

$90.5 \%$

$70.2 \%$

$93.5 \%$

$81.8 \%$

$89.4 \%$

$87.8 \%$

$90.4 \%$

$77.4 \%$

$92.9 \%$

$88.0 \%$

$68.2 \%$

$94.6 \%$

$51.7 \%$

$62.6 \%$

$71.8 \%$

$61.5 \%$

$75.3 \%$

$94.2 \%$

$76.0 \%$

$84.9 \%$

$82.1 \%$

$70.0 \%$

$77.9 \%$

$75.7 \%$

$73.9 \%$

$80.1 \%$

$83.6 \%$

$50.5 \%$

$33.7 \%$

200

share - soc

$\%$ Change

$76.0 \% \quad 71.5 \% \quad-4.5 \%$

$-4.5 \%$
$25.9 \%$

$\begin{array}{lll}41.9 \% & 67.8 \% & 25.9 \% \\ 65.8 \% & 67.2 \% & 1.4 \%\end{array}$

$\begin{array}{lll}65.8 \% & 67.2 \% & 1.4 \% \\ 46.3 \% & 48.2 \% & 2.0 \%\end{array}$

$37.8 \% \quad 43.1 \% \quad 5.3 \%$

$73.7 \% \quad 77.2 \% \quad 3.4 \%$

$60.1 \% \quad 58.1 \% \quad-2.1 \%$

$80.1 \% \quad 88.2 \% \quad 8.1 \%$

$67.4 \% \quad 69.6 \% \quad 2.2 \%$

$96.4 \% \quad 93.9 \% \quad-2.6 \%$

$79.1 \% \quad 83.5 \% \quad 4.5 \%$

$85.5 \% \quad 87.9 \% \quad 2.4 \%$

$64.3 \% \quad 64.7 \% \quad 0.4 \%$

$\begin{array}{lll}83.2 \% & 90.6 \% & 7.4 \%\end{array}$

$63.0 \% \quad 71.8 \% \quad 8.9 \%$

$82.5 \% \quad 85.4 \% \quad 2.9 \%$

$\begin{array}{lll}77.9 \% & 83.9 \% & 6.0 \%\end{array}$

$82.4 \% \quad 88.5 \% \quad 6.1 \%$

$69.6 \% \quad 71.1 \% \quad 1.5 \%$

$91.1 \% \quad 90.0 \% \quad-1.2 \%$

$82.7 \% \quad 84.8 \% \quad 2.1 \%$

$48.7 \% \quad 45.2 \% \quad-3.4 \%$

$90.8 \% \quad 93.4 \% \quad 2.6 \%$

$28.5 \% \quad 32.1 \% \quad 3.6 \%$

$\begin{array}{lll}28.4 \% & 54.0 \% & 5.6 \%\end{array}$

$47.6 \% \quad 53.1 \% \quad 5.5 \%$

$44.3 \% \quad 48.2 \% \quad 4.0 \%$

$51.8 \% \quad 55.6 \% \quad 3.8 \%$

$90.3 \% \quad 85.4 \% \quad-4.9 \%$

$56.0 \% \quad 65.7 \% \quad 9.7 \%$

$\begin{array}{lll}77.9 \% & 80.5 \% & 2.6 \%\end{array}$

$\begin{array}{lll}73.1 \% & 76.8 \% & 3.6 \%\end{array}$

$62.9 \% \quad 61.0 \% \quad-2.0 \%$

$68.0 \% \quad 71.6 \% \quad 3.6 \%$

$72.5 \% \quad 83.0 \% \quad 10.5 \%$

$66.0 \% \quad 68.4 \% \quad 2.4 \%$

$73.6 \% \quad 75.1 \% \quad 1.5 \%$

$86.3 \% \quad 85.1 \% \quad-1.3 \%$

$\begin{array}{lll}41.7 \% & 43.7 \% & 2.0 \% 38\end{array}$

$19.0 \% \quad 20.7 \%$

$1.7 \%$

FD index

Source: Authors' computations from PNAD 2002 and 2007 and from US firm level data from S\&P 1500 index (available at Bloomberg). See Section II in the main text for specifics.

$-0.54$

0.25

$-0.02$

$-0.43$

0.09

0.25

0.51

$-0.04$

$-1.68$

0.05

$-0.17$

$-0.96$

0.13

0.33

0.51

$-0.20$

$-0.23$

0.07

0.40

$-0.45$

0.69

$-0.59$

1.07

0.08

1.12

0.46

0.84

0.53

1.27

$-0.62$

0.16

$-1.55$

$-1.30$

$-0.67$

1.26

$-0.14$

0.13

$-0.10$

$-0.86$

0.05 
Table 2: Decomposition of aggregate labor formalization between self-employed workers, small and larger Firms

(percent)

This Table provides a decomposition of changes in the aggregate ratio of Formal Employment to Total Employment Using Equations (1) and (2) in the main text. It decomposes changes in formalization as a sum of effects within and between each size category (self-employed, Small Firms, and Larger firms) over distinct time periods, with "SE" denoting self-employment, "S" denoting firms of 2-10 employees, and "L" denoting firms with 11 or more employees. (F/E)j refers to the formality rate for size category j. Ej/E refers to the employment share in size category j. For the formality measure "carteira assinada", employment is split into workers employed in small (2-10) and larger firms (>11) only, since category self-employment is not included because "carteira assinada" only refers to employees.

\section{Labor Contract Definition}

("carteira assinada")

\begin{tabular}{|c|c|c|c|c|c|c|}
\hline & $\Delta(\mathrm{F} / \mathrm{E})$ & $==-$ & $\Delta(\mathrm{F} / \mathrm{E})_{\mathrm{s}}\left(\overline{\left.\mathrm{E}_{\mathrm{s}} / \mathrm{E}\right)}\right.$ & $\Delta\left(E_{s} / E\right) \overline{(F / E}_{s}$ & $\Delta(\mathrm{F} / \mathrm{E})_{\mathrm{L}}\left(\overline{\left.\mathrm{E}_{\mathrm{L}} / \mathrm{E}\right)}\right.$ & $\Delta\left(\mathrm{E}_{\mathrm{L}} / \mathrm{E}\right)(\overline{\mathrm{F} / \mathrm{E}})_{1}$ \\
\hline 2002-2007 & 100 & & 41.6 & -22.0 & 40.1 & 40.3 \\
\hline 2002-2004 & 100 & & 33.5 & -38.6 & 32.2 & 72.9 \\
\hline 2004-2007 & 100 & & 44.7 & -14.1 & 43.8 & 25.7 \\
\hline
\end{tabular}

\section{Social Security Definition:}

("contribuicao a previdencia)

\begin{tabular}{|c|c|c|c|c|c|c|c|c|}
\hline & $\Delta(\mathrm{F} / \mathrm{E})$ & $==$ & $\Delta(\mathrm{F} / \mathrm{E})_{\mathrm{se}}\left(\mathrm{E}_{\mathrm{se}} \overline{\mathrm{E}}\right)$ & $\Delta\left(\mathrm{E}_{\mathrm{se}} / \mathrm{E}\right)(\mathrm{F} / \mathrm{E})_{\mathrm{se}}$ & $\Delta(\mathrm{F} / \mathrm{E})_{\mathrm{s}} \overline{\left(\mathrm{E}_{\mathrm{s}} / \mathrm{E}\right)}$ & $\Delta\left(\mathrm{E}_{\mathrm{s}} / \mathrm{E}\right)\left(\overline{\mathrm{F} / \mathrm{E})_{\mathrm{s}}}\right.$ & $\Delta(\mathrm{F} / \mathrm{E})_{\mathrm{L}}\left(\overline{\left.\mathrm{E}_{\mathrm{L}} / \mathrm{E}\right)}\right.$ & $\Delta\left(\mathrm{E}_{\mathrm{L}} / \mathrm{E}\right)(\mathrm{F} / \mathrm{E})_{\mathrm{L}}$ \\
\hline 2002-2007 & 100 & & 5.4 & -8.2 & 30.5 & -7.2 & 26.9 & 52.7 \\
\hline 2002-2004 & 100 & & 1.5 & -14.3 & 17.7 & -15.3 & 11.8 & 98.5 \\
\hline 2004-2007 & 100 & & 6.7 & -5.7 & 35.1 & -3.8 & 33.1 & 34.6 \\
\hline
\end{tabular}

Source: Authors' computations based on PNAD. 
Table 3. Formal Employment and Financial Dependence: Panel Regressions without size break

This table reports GLS regressions of the share of formal to total employment in industry $\mathrm{j}$ on time and industry dummies plus the interaction of term of external financial dependence by industry with aggregate credit to GDP. For each regresion only the coefficient on the interaction term is reported. The panel regression spans 40 sectors over the period 2002-2007.

\section{Dependent variable: Formal employment/ total employment}

\begin{tabular}{|c|c|c|c|c|}
\hline \multirow{2}{*}{$\begin{array}{c}\text { Formal employment } \\
\text { definition: }\end{array}$} & \multicolumn{2}{|c|}{ Financial Deepening Indicators } & \multirow[b]{2}{*}{ Observations } & \multirow[b]{2}{*}{ Sectors } \\
\hline & Credit to private sector/GDP & Credit to firms/GDP & & \\
\hline Social security & $\begin{array}{c}0.1079^{\star \star \star} \\
(0.037)\end{array}$ & $\begin{array}{l}0.2161^{\star \star} \\
(0.098)\end{array}$ & 240 & 40 \\
\hline Carteira & $\begin{array}{c}0.1025^{\star \star \star} \\
(0.027)\end{array}$ & $\begin{array}{c}0.2189 * \star \star \\
(0.061)\end{array}$ & 240 & 40 \\
\hline
\end{tabular}

Robust Standard errors in parenthesis. * Significant at 10\%; ** significant at 5\%; ***significant at 1\% 
This table reports GLS regressions where the dependent variable is the share of formal to total employment in industry $\mathrm{j}$, and formal employment is defined as employment of those reported to be registered workers with the labor ministry ("carteira"). The explanatory variables include interaction of term of external financial dependence by industry with aggregate credit to GDP as in equation 3 of the main text. Panel regressions were run for each for each firm size segment (the one-person firm or "self-employed" is excluded because he/she does not have "carteira" by definition). Only the coefficient on the financial dependence on the financial dependence*credit interaction term is reported. The panel spans the period 2002-2007.

\section{Dependent variable: Formal employment/Total Employment}

\begin{tabular}{|c|c|c|c|c|}
\hline \multirow[b]{3}{*}{ Firms with 2-10 employees } & \multicolumn{2}{|c|}{ Financial Deepening Indicators } & \multirow[b]{2}{*}{ Observations } & \multirow[b]{2}{*}{ Sectors } \\
\hline & Credit to private sector/GDP & Credit to firms/GDP & & \\
\hline & $\begin{array}{c}0.2067 * * * \\
(0.0446)\end{array}$ & $\begin{array}{c}0.4218^{* * *} \\
(0.1146)\end{array}$ & 156 & 26 \\
\hline $\begin{array}{l}\text { Firms with more than } \\
11 \text { employees }\end{array}$ & $\begin{array}{c}0.1111^{* * *} \\
(0.0192)\end{array}$ & $\begin{array}{l}0.2168 * * * \\
(0.0575)\end{array}$ & 240 & 40 \\
\hline
\end{tabular}

Robust Standard errors in parenthesis. * Significant at 10\%; ** significant at 5\%; significant at 1\% 
Table 5: Formal Employment and Financial Dependence: Panel Regressions of Within Size Effects

(Social Security Definition of Formality)

This table reports GLS regressions where the dependent variable is the share of formal to total employment in industry $\mathrm{j}$, and formal employment is defined as employment of those reported to be contributors to social security. The explanatory variables include time and industry dummies plus the interaction term of external financial dependence index by industry with aggregate credit to GDP as in equation 3 in main text. For each panel regression, the sample was broken down in the three size segments reported. Only the coefficient on the financial dependence*aggregate credit interaction term is reported. The panel spans the period 2002-2007.

Dependent variable: Formal employment/total employment

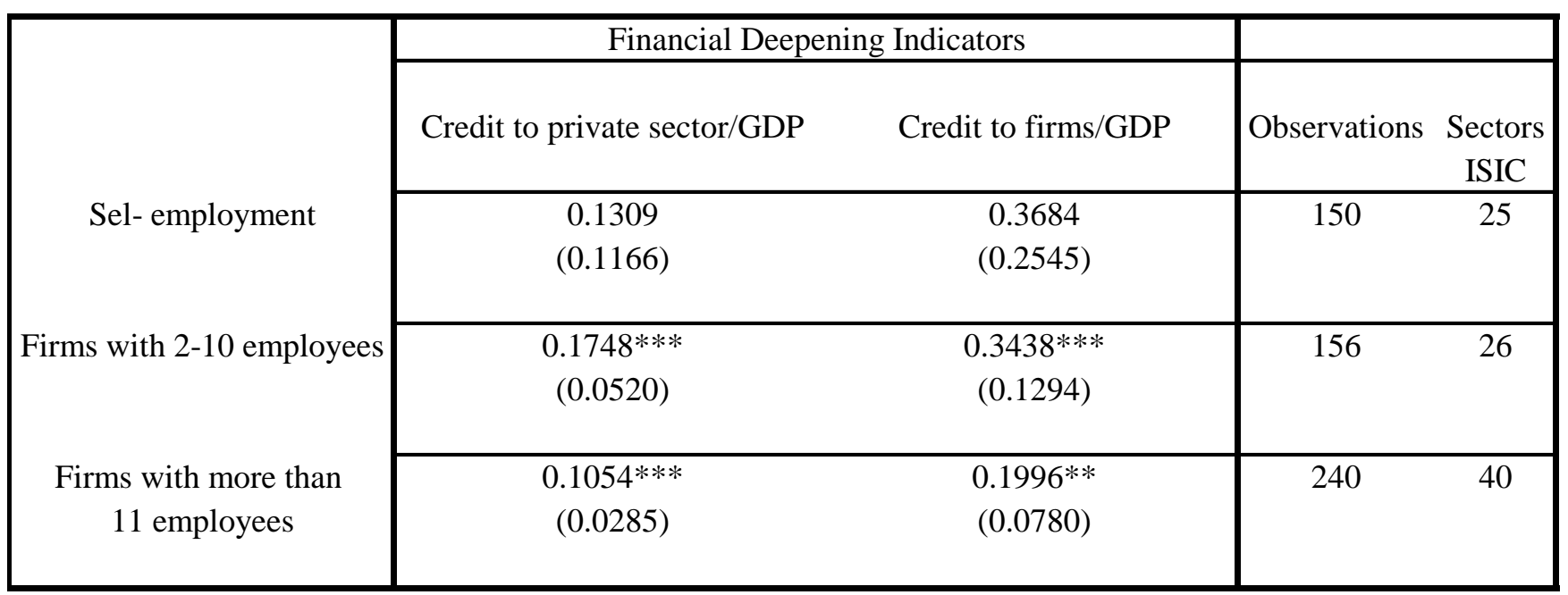

Robust Standard errors in parenthesis. * Significant at $10 \%$; **significant at 5\%; significant at $1 \%$ 


\section{Table 6. Formal Employment and Financial Dependence: Panel Regressions of Between Size Effects}

This table reports GLS regressions where the dependent variable is the share of employment in industry $\mathrm{j}$ to total employment in all sectors. The explanatory variables include time and industry dummies plus the interaction term of the external financial dependence index by industry with aggregate credit to GDP, as in equation 4 in main text. For each panel regression, the sample was broken down in the three size segments reported and two alternative indicators of credit were considered (private sector including households and excluding households, i.e., with firms only). Only the coefficient on the financial dependence*aggregate credit interaction term is reported. The panel spans the period 2002-2007.

\section{Dependent variable: Employment in the respective firm size segment/total employment}

\begin{tabular}{|c|c|c|c|c|}
\hline & \multicolumn{2}{|c|}{ Financial Deepening Indicators } & \multirow[b]{2}{*}{ Observations } & \multirow[b]{2}{*}{ Sectors } \\
\hline & Credit to private sector/GDP & Credit to firms/GDP & & \\
\hline Self- employment & $\begin{array}{l}-0.0848 * \\
(0.0475)\end{array}$ & $\begin{array}{l}-0.1470 \\
(0.1120)\end{array}$ & 150 & 25 \\
\hline Firms with 2-10 employees & $\begin{array}{c}0.0353 \\
(0.0346)\end{array}$ & $\begin{array}{c}0.0941 \\
(0.0754)\end{array}$ & 150 & 25 \\
\hline $\begin{array}{c}\text { Firms with more than } \\
11 \text { employees }\end{array}$ & $\begin{array}{c}0.0448 \\
(0.0592)\end{array}$ & $\begin{array}{c}0.0526 \\
(0.1337)\end{array}$ & 150 & 25 \\
\hline
\end{tabular}

Robust Standard errors in parenthesis. * Significant at 10\%; ** significant at 5\%; ***significant at $1 \%$ 
Table 7: Formal Employment and Financial Dependence: Panel Regressions of Within Sector Effects Using a Financial Dependence Dummy

This table reports GLS regressions where the dependent variable is the share of formal to total employment in industry $\mathrm{j}$, and where formal employment is measured as either the "carteira" or the social security contribution definition. The explanatory variables include time and industry dummies plus an interaction term consisting of the product of a dummy on financial dependence ( 1 for high financial dependence) by industry times aggregate credit to GDP as in equation 3 in main text. For each panel regression, the sample was broken down in the three size segments reported. Only the coefficient on the financial dependence*aggregate credit interaction term is reported. The panel spans 2002-2007.

\section{Dependent variable: Formal employment/total employment}

\begin{tabular}{|c|c|c|c|c|}
\hline & \multicolumn{2}{|c|}{ Social Security Definition } & \multicolumn{2}{|c|}{ Cartera Definition } \\
\hline & Credit to private sector/GDP & Credit to firms/GDP & Credit to private sector/GDP & Credit to firms/GDP \\
\hline Self-employment & $\begin{array}{c}0.1316 \\
(0.0833)\end{array}$ & $\begin{array}{l}0.3102^{*} \\
(0.188)\end{array}$ & - & - \\
\hline Firms with 2-10 employees & $\begin{array}{c}0.1208 \\
(0.0846)\end{array}$ & $\begin{array}{c}0.2105 \\
(0.1999)\end{array}$ & $\begin{array}{c}0.1236 \\
(0.0935)\end{array}$ & $\begin{array}{c}0.2324 \\
(0.2142)\end{array}$ \\
\hline $\begin{array}{l}\text { Firms with more than } \\
11 \text { employees }\end{array}$ & $\begin{array}{c}0.1309^{* * *} \\
(0.0308)\end{array}$ & $\begin{array}{c}0.2554^{* * *} \\
(0.0867)\end{array}$ & $\begin{array}{l}0.0810^{* *} \\
(0.0356)\end{array}$ & $\begin{array}{l}0.1568^{*} \\
(0.0879)\end{array}$ \\
\hline
\end{tabular}

Robust Standard errors in parenthesis. * Significant at 10\%; **significant at 5\%; * significant at $1 \%$ 


\section{Table 8. Panel Regressions Using the Money Market Interest Rate as the measure of Financial Deepening}

This table reports GLS regressions where the dependent variable is the share of formal to total employment in industry $\mathrm{j}$ (Panel A), or the share of employment in sector $\mathrm{j}$ in the sum of employment in all sectors (Panel B). Formal employment is measured as either the "carteira" or the social security ("SS")contribution definition. The explanatory variables include time and industry dummies plus an interaction term which now uses the money market interest rate as a measure of financial deepening to be interacted the external financial dependency index as in equation 3 in the main text. For each panel regression, the sample was broken down in the three size segments reported.

Only the coefficient on the financial dependence*interest rate interaction term is reported. The panel spans 2002-2007.

\section{A. Dependent variable: Formal employment/Employees ("within" regression)}

\begin{tabular}{|c|c|c|c|c|c|c|}
\hline & \multicolumn{2}{|c|}{ Dependence on external finance as Dummy } & \multicolumn{2}{|c|}{ Dependence on external finance as index } & \multirow[b]{2}{*}{ \# obs. } & \multirow[b]{2}{*}{ Sectors } \\
\hline & Formalization_SS & Formalization Carteira & Formalization_SS & Formalization Carteira & & \\
\hline Self-employment & $\begin{array}{l}-0.0133 \\
(0.1178)\end{array}$ & NA & $\begin{array}{l}-0.0069 \\
(0.1452)\end{array}$ & NA & 150 & 25 \\
\hline Firms with 2-10 employees & $\begin{array}{c}-0.2823 * * * \\
(0.086)\end{array}$ & $\begin{array}{l}-0.2513 * * * \\
(0.0944)\end{array}$ & $\begin{array}{c}-0.2579 * * * \\
(0.053)\end{array}$ & $\begin{array}{l}-0.2536 * * * \\
(0.0592)\end{array}$ & 156 & 26 \\
\hline $\begin{array}{c}\text { Firms with more than } \\
11 \text { employees }\end{array}$ & $\begin{array}{c}-0.1514^{* * *} \\
(0.029)\end{array}$ & $\begin{array}{l}-0.0844^{* *} \\
(0.0407)\end{array}$ & $\begin{array}{c}-0.1334 * * * \\
(0.0207)\end{array}$ & $\begin{array}{c}-0.1261^{* * *} \\
(0.0204)\end{array}$ & 240 & 40 \\
\hline
\end{tabular}

Robust Standard errors in parenthesis. * Significant at 10\%; ** significant at 5\%; significant at 1\%

\section{Dependent variable: Employment in the respective firm size segment/total employment ("between regression")}

\begin{tabular}{|c|c|c|c|c|}
\hline & Dependence on external finance as Dummy & Dependence on external finance as index & \# obs. & Sectors \\
\hline Self-employment & $\begin{array}{c}0.1892 \\
(0.1357)\end{array}$ & $\begin{array}{c}0.1097^{*} \\
(0.0591)\end{array}$ & 150 & 25 \\
\hline Firms with 2-10 employees & $\begin{array}{l}-0.0672^{*} \\
(0.0407)\end{array}$ & $\begin{array}{l}-0.0473 \\
(0.0386)\end{array}$ & 150 & 25 \\
\hline $\begin{array}{l}\text { Firms with more than } \\
11 \text { employees }\end{array}$ & $\begin{array}{c}-0.2748^{* *} \\
(0.1092)\end{array}$ & $\begin{array}{l}-0.0336 \\
(0.0693)\end{array}$ & 150 & 25 \\
\hline
\end{tabular}

Robust Standard errors in parenthesis. * Significant at 10\%; ** significant at 5\%; significant at 1\% 


\section{Table 9. Panel Regressions Using Bank Intermediation Spread as the measure of Financial Deepening}

This table reports GLS regressions where the dependent variable is the share of formal to total employment in industry $\mathrm{j}$ (Panel A), or the share of employment in sector $\mathrm{j}$ in the sum of employment in all sectors (Panel B). Formal employment is measured as either the "carteira" or the social security ("SS") contribution definition. The explanatory variables include time and industry dummies plus an interaction term which now uses the lending minus the money market interest spread as a measure of financial deepening to be interacted the external index financial dependency as in equation 3 in the main text. For each panel regression, the sample was broken down in the three size segments reported. Only the coefficient on the financial dependence*interest rate interaction term is reported. The panel spans 2002-2007.

\section{A. Dependent variable: Formal employment/Employees ("within" regression)}

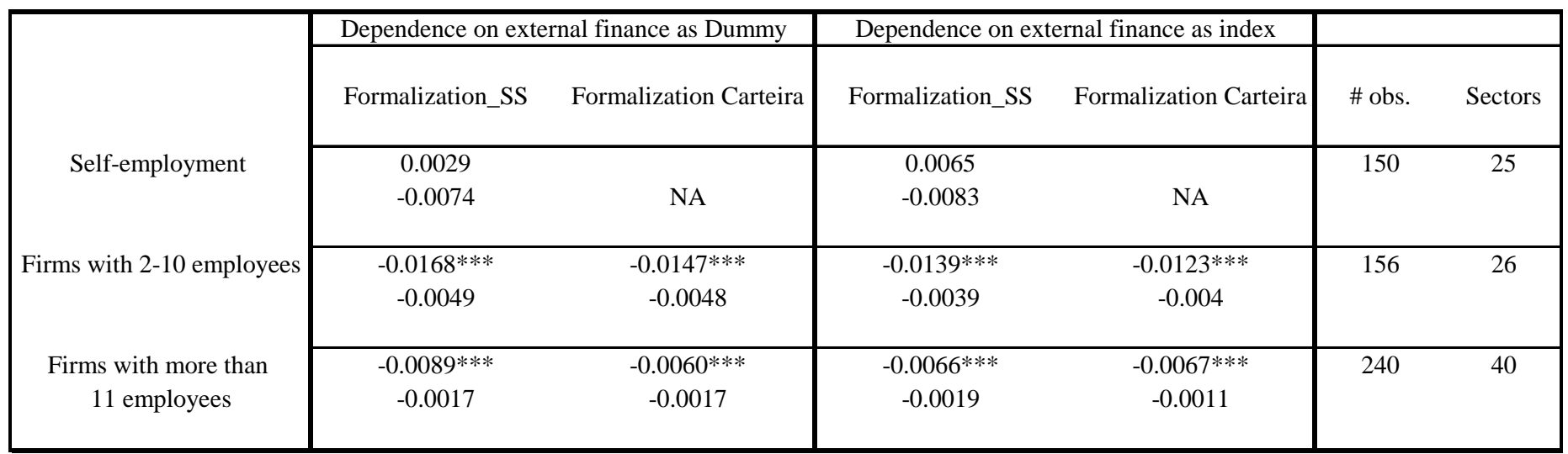

Robust Standard errors in parenthesis. * Significant at $10 \%$; ** significant at $5 \%$; significant at $1 \%$

Each entry corresponds to a separate regression of formality rates in industry $\mathrm{j}$ on time and industry dummies and the interaction of a measure of credit interacted with External Dependence by industry. For each regresion only the coefficient on the inter

\section{Dependent variable: Employment in the respective firm size segment/total employment ("between regression")}

\begin{tabular}{|c|c|c|c|c|}
\hline & Dependence on external finance as Dummy & Dependence on external finance as index & \# obs. & Sectors \\
\hline Self-employment & $\begin{array}{r}0.0081 \\
-0.0083\end{array}$ & $\begin{array}{r}0.0045 \\
-0.0037\end{array}$ & 150 & 25 \\
\hline Firms with 2-10 employees & $\begin{array}{c}-0.0042 * \\
-0.0022\end{array}$ & $\begin{array}{l}-0.0026 \\
-0.0023\end{array}$ & 150 & 25 \\
\hline $\begin{array}{l}\text { Firms with more than } \\
11 \text { employees }\end{array}$ & $\begin{array}{l}-0.0026 \\
-0.0083\end{array}$ & $\begin{array}{l}0.0045 \\
-0.0037\end{array}$ & 150 & 25 \\
\hline
\end{tabular}

Robust Standard errors in parenthesis. * Significant at 10\%; ** significant at 5\%; significant at $1 \%$ 


\section{Table 10. Formal Employment and Financial Deepening: Other Controls}

This table reports GLS regressions where the dependent variable is the share of formal to total employment in industry j (Panel A), or the share of employment in sector $\mathrm{j}$ in the sum of employment in all sectors (Panel B). Formal employment is measures as either the "carteira" or the social security ("SS") contribution definition. The explanatory variables include time and industry dummies plus an interaction term consisting of the ratio of aggregate credit to GDP as a measure of financial deepening which is interacted the external

financial dependency index as in equation 3 in the main text. For each panel regression, the sample was broken down in the three size

segments reported. The regressions also comprise real GDP growth and real exchange rate (\%) change as additional controls. The panel spans $2002-2007$.

\section{Dependent variable: Formal employment/Employees ("within" regression)}

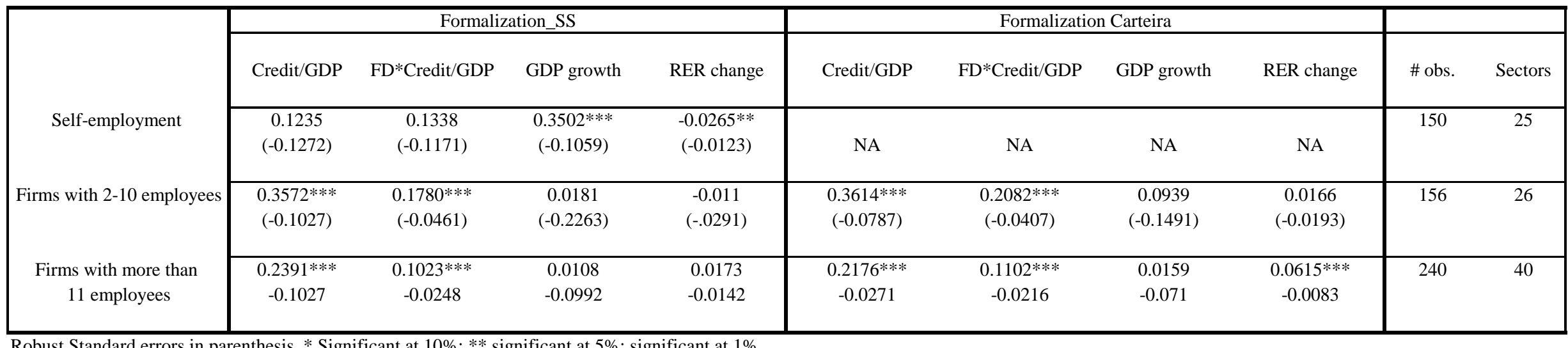

Robust Standard errors in parenthesis. * Significant at 10\%; ** significant at 5\%; significant at 1\%

Dependent variable: Employment in the respective firm size segment/total employment ("between regression")

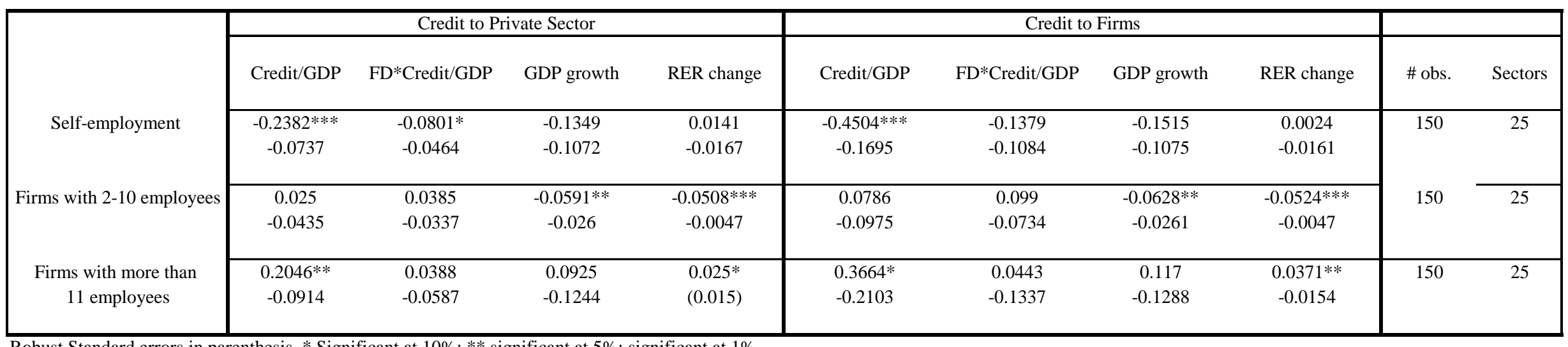

Robust Standard errors in parenthesis. * Significant at 10\%; ** significant at 5\%; significant at $1 \%$ 


\section{Table 11. Formal Employment and Financial Deepening: Weighted Generalized Least Square Regressions}

This table reports GLS regressions where the dependent variable is the share of formal to total employment in industry $\mathrm{j}$ (Panel A), or the share of employment in sector $\mathrm{j}$ in the sum of employment in all sectors (Panel B). Formal employment is measured either the "carteira" or the social security ("SS") contribution definition. The explanatory variables include time and industry dummies plus an interaction term consisting of the ratio of aggregate credit to GDP as a measure of financial deepening which is interacted the external

financial dependency index as in equation 3 in the main text. For each panel regression, the sample was broken down in the three size segments reported. In the regressions, each sector is weighed by the number of observations. The panel spans 2002-2007.

\section{A. Dependent variable: Formal employment/Employees ("within" regression)}

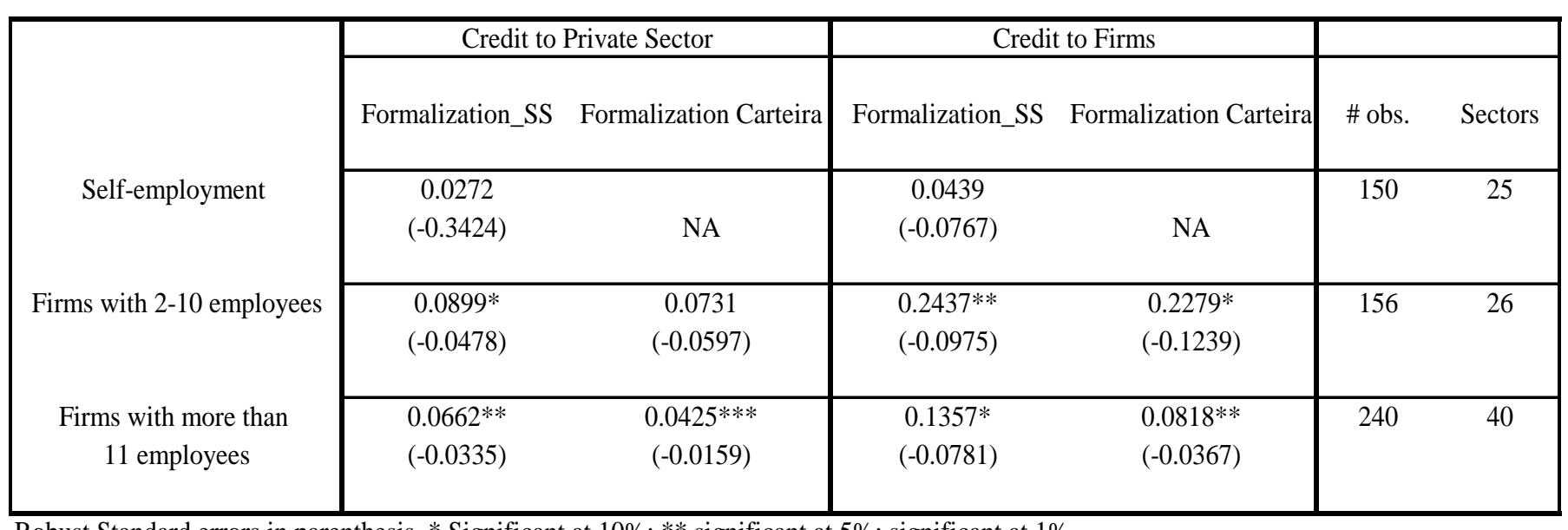

Robust Standard errors in parenthesis. * Significant at 10\%; ** significant at 5\%; significant at $1 \%$

Dependent variable: Employment in the respective firm size segment/total employment ("between regression")

\begin{tabular}{|c|c|c|c|c|}
\hline & Credit to Private Sector & Credit to Firms & \# obs. & Sectors \\
\hline Self-employment & $\begin{array}{c}-0.1696 * * * \\
(-0.065)\end{array}$ & $\begin{array}{c}-0.2768 \\
(-0.1763)\end{array}$ & 150 & 25 \\
\hline Firms with 2-10 employees & $\begin{array}{l}0.1085^{* * *} \\
(-0.0264)\end{array}$ & $\begin{array}{c}0.2170^{* * *} \\
(-0.0657)\end{array}$ & 150 & 25 \\
\hline $\begin{array}{l}\text { Firms with more than } \\
11 \text { employees }\end{array}$ & $\begin{array}{c}0.0398 \\
(-0.0545)\end{array}$ & $\begin{array}{c}0.0436 \\
(-0.1212)\end{array}$ & 150 & 25 \\
\hline
\end{tabular}

Robust Standard errors in parenthesis. * Significant at 10\%; ** significant at 5\%; significant at 1\% 